\title{
DHFR Gene
}

National Cancer Institute

\section{Source}

National Cancer Institute. DHFR Gene. NCI Thesaurus. Code C26538.

This gene is involved in biosynthesis, nucleotide metabolism and the immune response. 